\title{
Rights, Responsibilities and Regulation - The Three Rs of Education: a Consideration of the State's Control over Parental Choice in Education
}

\author{
Dr Sally Varnham \\ Faculty of Law, University of Technology, Sydney \\ PO Box 123 Broadway NSW 2007 Australia \\ Dr Joan Squelch \\ School of Business Law and Taxation, Curtin University of Technology, Perth \\ GPO Box U1987 WA 6845 Australia

\begin{abstract}
Perhaps the two views of education - the public or institutional versus the private or familial - are best seen as a contest between personal rights and freedoms held up against the power of the state to control the individual. ${ }^{1}$
\end{abstract}

Education is both a right and a responsibility. International instruments such as the International Covenant on Civil and Political Rights and the International Convention on the Rights of the Child affirm the right of all children to education. This right is spelt out in the education legislation of all states and territories in Australia. Education is not only free but it is compulsory for all children between certain ages. The obligation is imposed on parents (in accordance with definitions contained therein) to ensure that their children are both enrolled at and attend school. However, parental choice of education provider is allowed within each jurisdiction by way of state, private or church schools, all of which are registered and regulated to varying degrees by the state. The legislation of each jurisdiction also makes some degree of provision for parents who choose to opt out their children from any formal education setting and to educate them at home. Home education is also subject to state regulation.

The assumption by the state of the responsibility for education guides this policy and legislation. The argument for state control of all education, no matter how and by whom it is provided, is that the state has an overriding interest in ensuring the economic wellbeing of its citizens and the growth of its intellectual capital. The state acknowledges that the responsibility for education is shared with parents, primarily by providing penalties for parents who fail to ensure enrolment and attendance of their children at a school.

There is evidence that more and more parents in developed countries worldwide are choosing to educate their children at home, and anecdotal evidence suggests that Australia is part of this trend. To this end, the paper critically examines the balance and relationship between the exercise of parental choice and responsibility in education, and state regulation and control. It does so by examining the means by which the legislation of different jurisdictions allows for choice in the exercise of the right to education, with particular reference to home education; places limitations on that choice; and imposes control on the delivery of education outside state schools. 


\section{Introduction}

Education - whose right to choose, whose responsibility and whose control? Historically, parents were recognised as their children's primary educator. They were ultimately responsible for their children's education, socialisation and upbringing. Prior to the establishment of formal schools and the implementation of compulsory schooling, parents were responsible for educating their children at home. With the establishment of private schools, mostly operated by religious groups, schooling moved from the home to the more formalised classroom setting. The first Australian schools were established and operated by the Church of England at the time of British settlement in 1788. By the nineteenth century schools had been established by other denominations such as the Catholics, Methodists and Presbyterians. ${ }^{2}$ By 1895 all the Australian colonies had passed education acts which effectively removed state education from the church and established the responsibility of the state to educate children. ${ }^{3}$ Progressively, the provision and control of education came to be recognised as a state responsibility. Education is now seen as both a public function and a private matter.

For increasing numbers of children in Australia and elsewhere, school has returned to the home, with their parents as their teachers. The rise in popularity of home schooling raises important questions relating to the right of choice, the responsibility, and the control of education. In Australia, the increase in home education and new measures introduced in Victoria and Queensland in response, together with controversies concerning the public funding of private schools and the establishment of religious, particularly Islamic, schools have all served to highlight the issue of educational choice. This paper focuses on this choice in relation to home education.

In Australia, six primary reasons have been suggested for parents choosing to home school their children: ${ }^{4}$

... (i) religious beliefs; (ii) a heightened sense of parental responsibility for education; (iii) a commitment to high literacy and numeracy for their children; (iv) promotion of social development of their children and avoidance of negative peer influences; (v) practical reasons such as distance from school or financial need;

(vi) the special educational and health needs of their children.

Similar reasons are advanced in New Zealand. ${ }^{5}$ Religious beliefs feature highly in Australia, and also in the United States, and the primary organisations promoting home education, the Australian Christian Academy School of Distance Education and the Home School Legal Defense Association (HSLDA) respectively, have their foundations in the desire of parents to educate their children in an atmosphere of Christianity which is perceived to be lacking in the secular government education system. ${ }^{6}$ In the United States the debate is driven to a large measure, by the Christian belief in intelligent design rather than in science and evolution, which is currently incorporated in the state schools' curricula. It is reported that: 'The American religious Right are increasingly turning to home-schooling, lest their children may be exposed to the evils of sex, drugs or - heaven forbid - Darwin'. ${ }^{7}$ The form of Christianity of home schoolers tends to be outside the 'mainstream' religious dogma, such as Roman Catholic, Church of England or 
Presbyterian belief that is taught in denominational schools, and has thus come to be associated with fundamentalism in the minds of many.

This paper considers the right to education, and in particular home education, in the context of the relationship between the exercise of parental choice and responsibility on the one hand, and state regulation and control on the other. It discusses home education in Australia, but draws on comparisons with New Zealand and the United States.

\section{The Right to Education and Parental Choice}

Education is an inalienable right. This is borne out by various provisions in international instruments on human rights. Article 26(1) of the Universal Declaration of Human Rights 1948 provides that '[e]veryone has the right to education. Education shall be free, at least in the elementary and fundamental', and Article 13 of the International Covenant on Economic, Social and Cultural Rights 1966 (ICESCR) states that '[p]rimary education shall be compulsory and available free to all'. Similarly, Article 28(1)(a) of the United Nations Convention on the Rights of the Child 1999 (UNCROC) provides that '[s]tates Parties recognise the right of the child ${ }^{8}$ to education'. The scope of this right is further elucidated in Article 29 which sets out that such education should be directed at the development of the following aspects:

- the child's personality, talents and mental and physical abilities to their fullest potential;

- $\quad$ respect for human rights and fundamental freedoms;

- $\quad$ respect for the child's parents, his or her own cultural identity, language and values, for the national values of the country in which the child is living, the country from which he or she may originate, and for civilisations different from his or her own;

- the preparation of the child for responsible life in a free society, in the spirit of understanding, peace, tolerance, equality of sexes, and friendship among all peoples, ethnic, national and religious groups and persons of indigenous origin; and

- $\quad$ the development of respect for the natural environment.

International human rights instruments further recognise and emphasise the rights of parents to choose the kind of schooling they wish for their children and, therefore, to exercise some control over their children's education. For instance, Article 26(3) of the United Nations Declaration of Human Rights (1948) states that '[p]arents have a prior right to choose the kind of education that shall be given to their children'. According to Grover, ${ }^{9}$ UNCROC further supports the central role of parents in society and in the lives of their children. The primary role of parents (or legal guardians) in the overall development of the child is emphasised in several provisions of UNCROC: Article 14(2) requires that '[s]tates Parties shall respect the rights and duties of the parents and, when applicable, legal guardians, to provide direction to the child in the exercise of his or her right in a manner consistent with the evolving capacities of the child', and Article 18(1) states that '[...] parents or, as the case may be, legal guardians, have the primary responsibility for the upbringing and development of the child'. The rights of parents to determine the education and upbringing of their children are inextricably linked to parents' religious convictions and the rights of parents to have their children educated 
according to their religious beliefs. ICESCR provides that states Parties are obliged 'to have respect for the liberty of parents and, when applicable, legal guardians to choose for their children schools' and 'to ensure the religious and moral education of their children in conformity with their own convictions'. ${ }^{10}$ This is echoed in the International Covenant on Civil and Political Rights 1966 (ICCPR) which requires states Parties to have 'respect for the liberty of parents and, when applicable, legal guardians to ensure the religious and moral education of their children in conformity with their own convictions'. ${ }^{11}$

Behind these provisions is an implicit assumption of responsibility on the part of signatory states. ${ }^{12}$ There is an expectation that signatory states will provide basic education (i.e. at least free primary education) and establish the regulatory framework to ensure that children have access to education and that parents send their children to school, while at the same time recognise the right of parents to choose the kind of education they see fit for their children.

Parental choice in education is by and large a choice between private and public schooling, with some choice within each of those dual systems. In addition, there is a growing trend towards home education, whereby parents completely withdraw their children from the formal schooling sector and educate their children at home. Home education is defined as the 'education of school-aged children at home rather than in private or public settings'. ${ }^{13}$ Belfield and Levin describe home education as the 'ultimate in privatisation: the education of children who are home schooled is typically privately funded, privately provided and (almost fully) privately regulated'. ${ }^{14}$

There is little doubt that significant numbers of children are now being home educated. Although accurate and comprehensive statistics on home education are not available, the Home Education Association Inc predicts that Australia has 26,500 home educated students in 15,000 families nationally. ${ }^{15}$ In New Zealand, according to HSLDA, home schoolers comprise $1 \%$ of the total school population. ${ }^{16}$ In the United States, according to Yuracko, it is estimated that between 1.1 and 2 million children are home schooled. ${ }^{17}$ The question of why parents choose to home school their children is frequently answered with reference to the religious and political convictions of parents. The home education literature suggests the main reason for choosing home education is the desire by parents to provide their children with an education according to their religious convictions, citing the 'conflict between religious beliefs and the public school program', and the fact that 'parents home school in the belief that their children are better served when they themselves are the primary teachers'. ${ }^{18}$ In a study conducted by Green and HooverDempsey, it was concluded that parents choose home education because they believe they should be involved in their children's education; they have the ability to help their children succeed in learning and their circumstances make home schooling possible. ${ }^{19}$ In the United States there is also the desire of parents to protect children from the perceived dangers of the schoolyard. Apple ${ }^{20}$ (a home school critic) makes the following comment:

For an increasing number of parents, pubic schools are now seen as threatening in an even more powerful way. They are dangerous bodily; that is, they are seen as filled with physical dangers to the very lives of one's children. The spate of shootings in the 
United States has had a major impact on the feelings of insecurity that parents have about their children...

Although Australia signed UNCROC in January 1991, it has not been incorporated into Australian domestic law. Nonetheless, the right to education and parental choice in education is implemented by all Australian states and the two self-governing territories in their legislation, which also provide for education to be compulsory between certain ages. ${ }^{21}$ In making education compulsory there is an obligation on states to provide access to at least a basic education and minimum standards. However, although parents are obliged by law to send their children to school, the right of parents to alternative schooling is also recognised whereby parents may choose between private or public schools, or completely withdraw their children from the formal schooling sector and educate their children at home. All states in Australia recognise the right of parents to choose home education as an alternative option to public or private schools.

In the Australian Capital Territory, Chapter 5 of the Education Act 2004 (ACT) begins its express provisions relating to home education, by stating the following principles: ${ }^{22}$

(a) parents have the right to choose a suitable education environment for their children;

(b) there is a diversity of religious and educational philosophies held by parents providing home education for their children;

(c) the diversity of educational philosophies reflects the preferences of parents to particular forms of education for their children;

(d) home education is committed to -

(i) offering a board range of opportunities that foster in each child the development of the child's unique spiritual, emotional, physical and intellectual being; and

(ii) valuing the individual needs, interests and aptitudes of each child; and preparing each child to become an independent and effective local and global citizen.

Legislation in the other states is less explicit about the parents' right of choice and the objectives of home education. Nonetheless, they all allow for home education, which in some is framed as an exemption from compulsory schooling. In New South Wales, the Education Act 1990 states that one of its objectives is to 'allow children to be educated at home'. ${ }^{23}$ In Queensland 'parents have the responsibility of choosing a suitable education environment for their children, ${ }^{24}$ and parents may choose home education as an alternative to the formal school program. ${ }^{25}$ Western Australia 'recognise[s] the right of every child in the state to receive a school education'; and 'allow[s] that education to be given in a government school, a non-government school or at home' ${ }^{26}$ Victoria provides that 'parents have the right to choose an appropriate education for their child', which includes home education. ${ }^{27}$ South Australia specifies that children of compulsory school age must be enrolled in and attend a Government or a registered non-Government school; however children may be exempt and be educated at home. ${ }^{28}$ Likewise, Tasmania allows for children to be educated at home $\mathrm{e}^{29}$ and in the Northern Territory the requirement of compulsory education may be met by a parent who provides an 'education for the child that is efficient and suitable'. ${ }^{30}$ 
In New Zealand, section 3 of the Education Act 1989 states that there is a '[r]ight to free primary and secondary education' and section 8 states that there are '[e]qual rights to primary and secondary education'. The legislation makes no express provision for home schooling. Parents wishing to home school their children must apply for an exemption from compulsory enrolment and attendance. In order to be granted this exemption the Secretary of Education must be satisfied that the person: 'Will be taught at least as regularly and well as in a registered school ...' 31

In the United States parental choice is likewise of primary importance and home education has steadily grown. According to Yuracko 'home schooling is no longer a "fringe" phenomenon' and it is 'legal in all states'. ${ }^{32}$ However, a recent Californian appeals court decision, which has attracted much criticism and concern from the home education sector, has potentially put the brakes on home schooling there. In Re Rachael L. et el Persons Coming Under the Juvenile Court Law, Jonathon L and Mary Grace L. v Superior Court of the State of California for the County of Los Angeles ${ }^{33}$ a California Court of Appeal held that 'parents do not have a constitutional right to home school their children'. The Court determined that the parents concerned were not entitled to home school their children because they could not demonstrate that the exemptions to attend public or private schooling applied. In particular, the parent/tutors did not hold the required valid teaching credential. Justice H. Walter Croskey stated that: 'parents who fail to [comply with school enrolment laws] may be subject to a criminal complaint against them, found guilty of an infraction, and subject to imposition of fines or an order to complete a parent education and counseling program'. ${ }^{34}$ However, on appeal, the Court of Appeal of the State of California ruled that parents may home school their children even if they do not have teaching credentials. ${ }^{35}$ The Court did however note that the right of parents to home school their children is not an absolute right and it 'may [be] constitutionally overridden in order to protect the safety of a child who has been declared dependent'. The appellate court also directed the trial court to consider whether the safety of the children necessitated removing them from home schooling.

These cases focus attention on the tension between state and individual rights and responsibilities in the education context. Those who advocate for home education argue that it is an incontestable right of parents to choose the manner in which their children will be educated. Historically, this view has been driven by a belief in parental autonomy in relation to their religious beliefs and values.

Opponents of home schooling argue that it is 'detrimental to the common good and to the equity and quality of education for all'. ${ }^{36}$ Because traditionally the home schooling movement has been largely borne out of the conflict between the religious beliefs of parents and the secular state school system, it has become strongly associated with fundamentalism and separatism. The trend of parents 'cocooning' their children at home has lent weight to the argument that home schooling is a direct attack on the public school system which is further weakened by fearful parents.

\section{Responsibility - State or Parental?}


A fundamental belief that the responsibility for and control over education lies with the parents drives the majority of those who home school. Harding cites the United States research of Ray ${ }^{37}$ in stating that 'home educating families share a common belief that the education of children is primarily their responsibility'. ${ }^{38}$ Michael Farris, a founder and previous president of HSLDA, argues that 'the right of parents to control the education of their children is so fundamental that it deserves the extraordinary level of protection as an absolute right'. ${ }^{39}$ In choosing home education, parents assume ultimate responsibility for and control over their children's education. However, education is undeniably an important responsibility of the state. In Brown $v$ Board of Education, the United States Supreme Court noted that 'education is perhaps the most important function of state and local governments'. ${ }^{40}$

Education is essentially a shared responsibility between the home and the state; 'education has never been the exclusive domain of the state' ${ }^{41}$ but it has a primary role to play. Where legislation recognises that parents have responsibility for the education of their children, that recognition is coupled with the responsibility of the state to ensure children receive a basic education. The primary responsibility of parents is to ensure their children attend school. Parents are legally required to ensure their children attend school regularly; failure to do so may be an offence. ${ }^{42}$ Parents are also expected to take an active role in their children's education in the school and at home. Active parental involvement and participation in their children's education is a key factor in achieving successful educational outcomes. However, the state is ultimately responsible for the provision and allocation of resources to establish schools and control the delivery of education. The state is also charged with the responsibility of ensuring that children receive an education that meets certain basic standards, of which parents are not entitled to opt out. The state is, therefore, arguably justified in the exercise of a degree of control over those parents educating their children at home.

In Australia, responsibility for the provision and control of school education lies with the states. The Education Act 1990 (NSW) is alone in placing the primary responsibility to educate on parents, and expressing the state's responsibility in terms of ensuring that every child receives a high quality education. Section 4 states that the principles on which the Act is based are:

(a) every child has the right to receive an education;

(b) the education of a child is primarily the responsibility of the child's parents;

(c) it is the duty of the State to ensure that every child receives an education of the highest quality;

(d) the principal responsibility of the State in the education of children is the provision of public education.

In New Zealand, the obligation of the state with regard to education was affirmed in a case that arose in the context of special education, The Attorney-General $v$ Daniels. ${ }^{43}$ The majority of judges of the Court of Appeal held that the right of all persons to education exists as a basic responsibility of the government to provide an education system. The government discharges its obligation by the provision of a state education system within a legislative framework. ${ }^{44}$ Keith $\mathrm{J}$ in delivering the judgment of the Court said: ${ }^{45}$ 
To repeat, while there are rights under the 1989 Act that can be enforced by court process [such as natural justice on suspension and expulsion], those rights do not include generally, and abstractly, formulated by the Judge [Baragwanath $\mathrm{J}$ of the High Court at first instance]. Rather, the rights are essentially those specifically established by and under legislation which, to recall the Judge's formulation, do in themselves provide for a regularity and system and are designed to ensure appropriate quality.

So, in essence 'education' is a general right to partake of a system as provided by and delivered pursuant to legislation, rather than a specific right, breach of which would be enforceable by individuals.

The case of Attorney-General $v$ Daniels is of primary importance in the context of educational responsibility and choice. The New Zealand Court of Appeal expressly accepted the removal by the state of the choice of special education facilities for students with special needs. By the disestablishment of these facilities, and the accompanying provision in the Education Act 1989 (NZ), ${ }^{46}$ parents of these children were no longer able to choose to have their children educated in a school or facility specifically constituted for that purpose. It could be argued that this judgment and the government policy which it implicitly supports casts doubt on the scope of parental choice in education generally.

While parents traditionally have had the right to determine and direct the development and nature of their children's education, states have increasingly taken on the responsibility to regulate all education. To this end, states set down the minimum standards and requirements for education. Moreover, although the centrality of parents' rights and responsibilities are legislated, it is also clear that states may intervene and impose obligations and regulations on parents such that the states' control and authority may trump the parents' rights and control over their children's development and education.

\section{Regulation of Home Education}

In Australia, New Zealand and the United States, there is the assumption that government funding of education is an investment in the future intellectual capital of the nation, which carries with it the right to control what, where, when and how children are to be taught in order to ensure educational quality. It is this control aspect which most troubles many of the parents who are committed to home education. As already noted, one of the primary reasons for parents choosing home education is so that they have full say and responsibility over the kind of education they wish their children to receive. While they have the right to choose home education, this is, nonetheless, inevitably subject to state regulation. In this regard, Reich argues that 'the state must not forbid home schooling but regulate it, and strictly enforce such regulations, so as to ensure that interests of the state and child are met'. ${ }^{47}$ Such regulation may extend over matters such as registration and deregistration, curriculum, study materials, hours of instruction, testing and evaluation, teaching credentials and home moderation visits. 
Each Australian state and territory has legislation which recognizes the state responsibility for education and provides for formal schooling, while at the same time recognising the right of parents to choose home education. Each education act contains the principles that underlie the state provision of education to varying degrees of specificity. As is noted above, the New South Wales Education Act 1990 (NSW) alone expressly spells out that parents have the primary responsibility to educate their children. However, Section 5 (d) contains the wording, within the objects of the Act, 'to allow children to be educated at home'. This wording is curious in light of the previous statement that the primary responsibility lies with parents. The use of the word 'allow' clearly emphasises the state's control of education. It is then provided that it is a condition of registration that the parent '.. must provide for the child to receive instruction that meets the relevant requirements of Part 3 [of the Act] relating to the minimum curriculum for schools' ${ }^{48}$ This provision, together with those relating to the cancellation of registration for home schooling ${ }^{49}$ further reinforces the state's control of education. Registration may be cancelled if the home schooler fails to provide education in compliance with the conditions, or fails to allow access to an authorised person to the premises where the education is being provided. ${ }^{50}$ The information required to be provided by a home schooling parent was at issue in the case of Boxx v Aquilina. ${ }^{51}$ The registration of the plaintiff to home school her six children had been cancelled by the Department of Education and Training on the basis that she had failed to supply the information it required relating to the educational progress of the children. The plaintiff argued that it should be enough that she advised that her education met the minimum requirements. This argument was a direct challenge to state regulation and it failed. In refusing the plaintiff's claim for substantive relief, the court upheld the state's authority generally over home schoolers.

The Australian Capital Territory Education Act 2004 (ACT) expressly recognises home education by its inclusion, together with state education, in its primary provisions ${ }^{52}$ It states that a high-quality education is based on the principle that 'school education and home education provide a foundation for a democratic society' and that 'school education and home education' should 'encourage parents to take part in the education of their children, and recognise their right to choose a suitable educational environment for their children'. ${ }^{53}$ The wording encourages debate as to whether the intention of this Act is to recognise the partnership of parents and the state in the education of children or whether it goes further, to a positive encouragement of home education. The weight of the latter view, however, is diminished by the provision for a system of registration for home education that is strongly regulative. ${ }^{54}$

In Western Australia, the School Education Act 1999 (WA), in similar vein to NSW and ACT, provides for a system of 'registration' of home education. It contains corresponding and arguably even more strongly prescriptive provisions. 'Home educator moderators' are appointed to evaluate the programs and the educational progress of children who are being home educated. ${ }^{55}$ Importantly the criteria for such evaluation include: ${ }^{56}$

(a) whether the child's educational progress is in accordance with -

(i) the curriculum framework under the Curriculum Council Act 1997; or

(ii) any condition to which an exemption under section 11 of that Act is subject; 
(b) the effect of the physical learning environment on the child's educational progress;

(c) any other matter which, in the opinion of the chief executive officer, is relevant to the child's education.

While home educators are required to implement the curriculum framework unless granted an exemption, ${ }^{57}$ the Department of Education does state that: ${ }^{58}$

\begin{abstract}
One of the key principles of the curriculum framework is flexibility. It is intended that the framework be used flexibly in the delivery and evaluation of home education. Parents who choose home education do so for a variety of reasons, and the forms of education that they wish to provide to their children are diverse. In implementing the framework, home educators structure learning opportunities according to their children's particular needs. Monitoring and reporting on the program and progress by the home educators will also be approached in a number of ways. Consistency is also important. The Curriculum Framework provides the learning outcomes expected of all students for assessment that is fair and contributes to continued learning.
\end{abstract}

Tasmania also provides for registration of home educators which may be subject to conditions, and which may be revoked if the parent has 'failed to comply with or contravened any condition of registration'; or if 'the Minister is satisfied it is in the best interests of the child to do so'. ${ }^{9}$

In South Australia and the Northern Territory, legislative provision for home education is on a different basis. In reality, this has little practical effect in terms of state regulation. ${ }^{60}$ A parent who wishes to home school is not expressly required to 'register'. Rather the choice to home school is accepted more by default, as an exemption from compulsory enrolment and from attendance in formal schooling. ${ }^{61}$ The Education Act 1996 (NT) provides that a parent may, as an alternative to enrolling a child in a government or nongovernment school, 'provide education for the child which is efficient and suitable'. ${ }^{62}$ However, the parent must obtain the consent of the Secretary of Education before providing such education and it is at the discretion of the Secretary whether the education complies with the standard of 'efficient and suitable'. A definition of 'efficient' or 'suitable' is absent. ${ }^{63}$ It is significant, however, that the Northern Territory Department of Employment, Education and Training has adopted the term 'home education' rather than 'home schooling' in a deliberate recognition that it has a less formal structure and curriculum basis than that which characterises schooling. ${ }^{64}$

In both Queensland and Victoria, recent changes have introduced a registration requirement for home schooling parents, together with an attendant measure of state regulation and control. ${ }^{65}$ In Victoria the legislation was introduced to implement government policy that dictates that ministerial responsibility requires the assurance that each child in the state receives a quality education. In order to comply with this duty, the legislation states that it must be in a position to enquire about how that education is provided and the quality of such education, and to take action if there are deficiencies. ${ }^{66}$ A new body called the Victorian Registration and Qualifications Authority has been created to ensure the accountability of all education providers for the quality of education, including that provided in the home. While home schooling parents are now required to register to educate their children, the approach to the review of home 
educators is, on the face of it, softer and less regulatory than in other states. Instead of their being subject to regular review, home schooling parents are required to present a yearly statutory declaration by which they attest that their children have 'completed a year of education that is of suitable standard and comprehensiveness according to their age'. Also in variance with other states, such as WA, home schooling parents are not required to teach curriculum. However, the Ministry states that: ${ }^{67}$

It is intended that the eight key learning areas form the broad framework in which young people completing their schooling should be familiar with in order to participate fully in the wider society.

The demonstration of 'regular and efficient instruction' may be fulfilled by the production of material such as learning materials and completed assessments. A review will only be undertaken where the Authority 'has reason to suspect or believe that a student registered for home schooling is not receiving regular and efficient instruction in the key learning areas'. This 'hands-off' approach is reinforced in the Act by the provision that Authority personnel are prohibited from visiting the residences of home schoolers without their consent. ${ }^{68}$

In Victoria, the changes have served to focus debate on what is the essence of home schooling. Home schoolers argue that by its very nature this form of children's learning and development is different and distinguishable to that provided within the formal school environment. The differences are summed up in the words of one New Zealand parent in referring to the forms supplied by the Ministry of Education to be completed in a home schooler's application for an exemption from compulsory school attendance: ${ }^{69}$

Parts of it [the form] are irrelevant. For example, describing the children's work area is, in our opinion, a complete waste of time. When the children are say baking, they will work in the kitchen. When they are shopping, they will be in the shop. They may do times tables and spelling in the car. They may do reading on Mum or Dad's lap - or in bed. They may be part of sports or other clubs. When writing, they may be at a computer, on the floor, at the dining table, or a lounge table, or a desk, depending on a number of factors ...

Another area that often causes concern is the request for a timetable. Many people at the Ministry cannot see that the children can learn as regularly as in a school without following a school-like timetable. This ignores the fact that home-based education is much more time-effective than classroom-based teaching. At home we don't generally have to take rolls, control 20-30 children etc...

The majority of parents who choose to home school their children are not opting to be 'alternate teachers' as a subset of the formal education system. Rather they choose to educate their children alternatively, applying different practices led by a different philosophy of how children learn and what they should be taught. In the words of Terry Harding, principal of the Australian Christian Academy: ${ }^{70}$

Governments are good at running schools and schooling. The Victorian Government has no experience of running home education, nor has it demonstrated any knowledge of the wonderful results of home schooling in Victoria, over the past twenty years. There is no good reason for it to interfere in 
such a specialised educational practice that is working so well ... The proposed changes indicate a gross lack of understanding of home schooling by the government.

It is useful to this discussion to consider the attitudes of the states in comparative jurisdictions towards their control of home education.

In New Zealand, it is the role of the Education Review Office (ERO) to conduct regular reviews of home educators in much the same way as it conducts reviews of formal schools. The aim is to judge first whether the child is being 'taught at least as regularly and as well as in a registered school' in terms of the legislation, and secondly, whether the terms upon which the exemption was granted are being met. The Certificate of Exemption may be revoked following an unsatisfactory ERO report. ${ }^{71}$ Home schooling parents argue that, while they are not legally bound to follow the national curriculum, the Ministry requirements for exemption from the formal education system endeavour to fit their schooling into that model. In their view, this attempt at 'standardisation' fails to recognise the essential differences which go to the nature of home education and that lend strength to parents' belief in the value of schooling their children themselves.

In the United States, there has long raged a debate concerning the state's regulation of home schooling. Having moved from being illegal in all states twenty years ago, home schooling is now, with the exception of California, ${ }^{72}$ considered to be a legitimate form of alternative education. This acceptance, however, is not without considerable, and often insurmountable control exercised over parents who choose to home school their children. The extent of the regulation varies from state to state. It may be either indirectly through regular testing of children ${ }^{73}$ or through other monitoring of their progress. Many states have a requirement, similar to that in the Californian Education Code, which requires parents to be 'certified'. ${ }^{74}$ Others, such as Massachusetts, require that home schooling is only permissible once the local district has determined the competency of parents to teach. ${ }^{75}$ In 1987, in a case known as Care and Protection of Charles, ${ }^{76}$ Hennessy CJ of the Supreme Judicial Court of that state held that the process for the approval of home schooling, which required parents to submit proposals that contained outlines of curriculum, resources and qualifications of 'teachers', did not violate parents' constitutional rights. He said:

While the parents contend, and we agree, that they possess a basic right in directing the education of their children, such a right is not absolute but must be reconciled with the substantial State interest in the education of its citizenry.

It is of interest to note however that, in 1998, also in the Massachusetts Supreme Judicial Court, the judge upheld the objections of two sets of home schooling parents to regular visits required by education district officers for the purposes of inspecting the instructional process. In Brunelle v Lynn Public Schools, Greany J rejected the arguments of the school district that home visits were necessary in order to ensure that the education plan was being implemented. He said: ${ }^{77}$

These reasons have to be measured against the nature of the home education involved in the plaintiff's case (namely, parents teaching their children in their 
own home) which in certain important ways can never be the equivalent of inschool education. For example, at home, there are not other students (except perhaps siblings), no classrooms, and no rigid schedules. Parents who teach at home stand in a very different relationship to their children than do teachers to a class full of other peoples' children. Teaching methods may be less formalized, but in the home setting may be more effective than those used in the classroom because the teacher-to-student ratio is maximized, a factor permitting close communication and monitoring on an individualized basis. It is obvious from these differences that, while the State can insist that the child's education be moved along in a way which can be objectively measured, it cannot apply institutional standards to this non-institutionalized setting. Furthermore, a requirement of home visits may call into play issues of family privacy in seeking to keep the home free of unwarranted intrusion.

This statement essentially encapsulates the arguments of home schoolers universally: that this is a type of learning which is so totally different any attempts at standardization serve little purpose.

\section{Conclusion}

There is much evidence pointing to the increased popularity of home education in Australia, ${ }^{78}$ New Zealand ${ }^{79}$ and the United States ${ }^{80}$ This trend is not without controversy in all three jurisdictions.

The reasons advanced for increasing numbers of parents educating their children at home are both positive and negative. They may be based on practical considerations, when there are factors which would make attendance at a school difficult, inappropriate, unsuitable, or not in the best interests of the child (because of peer bullying for example). Or there are philosophical or religious convictions behind the decision. In the US the trend towards home education is being enhanced by the science versus religion influence led by the 'intelligent design' belief. While religious conviction features among the reasons for home education in Australia there is as yet no evidence that 'creationism' is a significant factor here. Nor is there evidence in Australia that a fear of exposing children to danger is leading parents to 'cocoon' their children at home. Many believe this is just a matter of time. In the meantime, it may be said that a significant motivating factor of home-schooling parents in Australia is a feeling that education is primarily a parental responsibility. Some argue against all forms of state control.

The justification for state regulation and control of home schooling is its overriding interest in ensuring the economic well-being of its citizens and the growth of its intellectual capital. Opponents of home schooling, particularly in the United States, argue that to have a significant body of children outside the formal school setting is detrimental to the socialisation, community building and citizenship that is necessary for the existence of a democratic state.

The governments of states and territories have unquestionably assumed the responsibility for education by providing that it is free and compulsory for all citizens. This is in line with international instruments such as the International Convention on the Rights of the 
Child. Universally, the states acknowledge that the responsibility for education is shared with parents. A choice of alternatives to state education is provided in non-government schools. Home education is increasingly being recognised as another viable option for parents who wish to take a greater share of that responsibility. The question raised by many home schoolers, however, is whether this recognition goes far enough.

Within its responsibility for the provision of education, the state includes mechanisms for registration, evaluation and inspection of all education providers. These are aimed at ensuring that where education is not provided directly by the state it is nevertheless of a sufficient standard. Such inspection applies to all schools, whether they are government, non-government or alternative. The attitude of all the governments is that, for the wellbeing of all children, parents who home school should likewise be prepared to acknowledge and accept the need for review. It is equally important however, in the case of home education, that this review should recognise and celebrate the differences which lead many parents to choose to educate their children at home.

[1] Cooper, B.S. and Sureau, J. 2007. The Politics of Homeschooling: New Developments, New Challenges. Educational Policy 21, no. 1: 115.

[2] Stewart, D.J. and Russo, C.J. 2001. A comparative analysis of funding non-government schools in Australia and the United States. Education and the Law 13, no. 1: 29-41.

[3] Varnham, S. 2008. My home, my school, my island: Home education in Australia and New Zealand. PUBLIC SPACE: Journal of Law and Social Justice 2: 1-16, at p 8.

[4] Harding, T. and Farrell, A. 2003. Homeschooling and Legislated Education. Australia and New Zealand Journal of Law and Education 8, no. 125: 128-129, quoting from Harding, T.J.A. 1997. Why Australian Christian Academy Families in Queensland Choose to Home School: Implications for Policy Development. PhD Thesis, Queensland University of Technology.

[5] Reasons given in a 1998 report by the New Zealand Education Review Office (ERO) entitled The Quality of Homeschooling. http://www.ero.govt.nz.

[6] This is despite the fact that the education legislation of most Australian states and territories allow for the provision of general religious instruction and special religious instruction where a need is demonstrated: for example, Education Act 1990 (NSW) ss 32, 33 and Education (General Provisions) Act 2006 (Qld) ss 76-80. See Varnham, S. 2008. My home, my school, my island: Home education in Australia and New Zealand. PUBLIC SPACE: Journal of Law and Social Justice 2: 1-16, at p 8. As Monk writes: 'In particular in the USA, espousal of home education by the Christian Right is intimately connected to their opposition to what they perceive as secular, liberal and pluralistic indoctrination in public schools', Monk, D. 2003. Home Education: A Human Right? Evaluation and Research in Education 17, no.2-3: 157-166, 163

[7] See The God Curriculum. The Daily Telegraph Magazine (United Kingdom), April 72007 p28.

[8] A child is defined as a human being below the age of 18.

[9] Grover, S. 2007. Children's Human rights. Challenging Global Barriers to the Child Liberation Movement. Melbourne: Sandstone Academic Press.

[10] Article 13(3).

[11] Article 18(4). For a discussion of the right to education guaranteed by the European Convention of Human Rights see Monk, D. 2003. Home Education: A Human Right? Evaluation and Research in Education 17, no.2-3: 157-166.

[12] While both New Zealand and Australia have ratified these instruments and such ratification is generally believed to confer a legitimate expectation of adherence (The Minister of Ethnic Affairs $v$ Teoh (1995) 128 ALR 353), the extent of this principle was questioned by the High Court of Australia in Re Minister for Immigration and Multicultural Affairs; Ex Part Lam (2003) 195 ALR 502. 
[13] Green, C.L. and Hoover-Dempsey, K.V. 2007. Why do parents homeschool? A systematic examination of parent involvement. Education and Urban Society 29, no. 2: 264. See Jeub, C. 1994. Why parents choose home schooling. Educational Leadership 52, no.1: 50.

[14] Cited Cooper, B.S. and Sureau, J. 2007. The Politics of Homeschooling: New Developments, New Challenges. Educational Policy 21, no 1: 115. Although this is not the case in reality in Australia, New Zealand and the United States, see below.

[15] Strange, P. How many home educators in Australia. http://www.hea.asn.au/resources/disp_res.asp?type=4\&id=60.

[16] Home School Legal Defence Association http://www.hslda.org/hs/international/NewZealand/200211250.asp.

[17] Ibid 124.

[18] Cooper, B.S. and Sureau, J. 2007. The Politics of Homeschooling: New Developments, New Challenges. Educational Policy 21, no. 1: 115.

[19] Green, C.L. and Hoover-Dempsey, K.V. 2007. Why do parents homeschool? A systematic examination of parent involvement. Education and Urban Society 29, no. 2: 281.

[20] Cited in Cooper, B.S. \& Sureau, J. 2007. The Politics of Homeschooling: New Developments, New Challenges. Educational Policy 21, no.1: 114.

[21] Education Act 1999 (NSW) s 22; Education and Training Reform Act 2006 (VIC) s2.1.1; Education Act 1972 (SA) s 76; Education Act 1994 (TAS) s 4; Education (General Provisions) Act 2006 (QLD) s 177; School Education Act 1999 (WA) s 23; Education Act 2006 (ACT) ss10, 11; Education Act 1996 (NT) s21.

[22] Education Act 2004 (ACT) s 128.

[23] Education Act 1990 (NSW) s 5.

[24] Education (General Provisions) Act 2006 (QLD) s 77(a).

[25] Ibid s 199.

[26] School Education Act 1999 (WA) s 3.

[27] Education and Training Reform Act 2006 (VIC) s 1.2.1(d) and s 1.1.1(2)(c).

[28] Education Act 1972 (SA) s 76.

[29] Education Act 1994 (TAS) s 17.

[30] Education Act (NT) s 21.

[31] Education Act 1989 (NZ) s 21.

[32] Yuracko, K.A. 2008. Education off the grid: Constitutional Constraints on Homeschooling. California Law Review 96, no. 123: 124.

[33] (2008) B192878 Ct No JD00773. http://www.courtinfo.ca.gov/opinions/documents/B192878.PDF.

[34] Ibid at par 2.

[35] Jonathan L. et al Petitioners v The Superior Court of the Los Angeles County (2008) B192878 Ct No. JD00773. http://californiahomeschool.net/howTo/B192878August8.pdf.

[36] Cooper, B.S. and Sureau, J. 2007. The Politics of Homeschooling: New Developments, New Challenges. Educational Policy 21, no. 1: 110-131. It is of interest in this context to consider Germany where a key justification for compulsory schooling is the belief that it is vital to the existence of a democratic state and home schooling is outlawed - see Monk, D. 2003. Home Education: A Human Right? Evaluation and Research in Education 17, no.2-3: 157-166; also Leuffen v Federal Republic of Germany ECHR Application No: 00019844/92; and Konrad \& Ors v Germany ECHR Application No: 35504/03 where it was held that attendance at compulsory schooling is necessary for the integration children into society.

[37] Ray, B.D. 1992. Marching to the Beat of Their Own Drum: A Profile of Home Education Research. Salem, OR: Home School Legal Defence Association.

[38] Harding, T. and Farrell, A. 2003. Homeschooling and Legislated Education. Australia and New Zealand Journal of the Law and Education 8: 125, 128.

[39] Cited in Yuracko, K.A. 2008. Education off the grid: Constitutional Constraints on Homeschooling. California Law Review 96, no. 123: 127.

[40] 347 US 483, 493 (1954).

[41] Yuracko, K.A. 2008. Education off the grid: Constitutional Constraints on Homeschooling. California Law Review 96, no. 123: 145. 
[42] For example: Education Act 1999 (NSW) s 23; Education and Training Reform Act 2006 (VIC) s 2.1.2; Education Act 1972 (SA) s 76(3); Education Act 1994 (TAS) s 6(1); Education (General Provisions) Act 2006 (QLD) s 176; School Education Act 1999 (WA) s 23; Education Act 1996 (NT) s22(3).

[43] [2003] 2 NZLR 742 (CA).

[44] While concerned with different aspects, a similar view on the common issue relating to the right to education was taken very recently by the House of Lords in Ali (FC) v Headteacher and Governors of Lord Grey School [2006] UKHL 14, and in R (on the application of Begum (by her litigation friend, Rahman)) v Headteacher and Governors of Denbigh High School [2006] UKHL 15, delivered on the same day.

[45] [2003] 2 NZLR 742 (CA).

[46] s 8.

[47] Cited in Yuracko, K.A. 2008. Education off the grid: Constitutional Constraints on Homeschooling. California Law Review 96, no. 123: 131.

[48] Education Act 1990 (NSW) s 73(2)(b).

[49] Education Act 1990 (NSW) s 74.

[50] Education Act 1990 (NSW) s 74.

[51] [2000] NSWSC 166 (15 March 2000).

[52] Contained in Chapter 5 of the Education Act 2004 (ACT).

[53] Education Act 2004 (ACT) s 4(2)(b)(iii).

[54] Education Act 2004 (ACT) ss 130-132.

[55] School Education Act 1999 (WA) s 50. Such evaluations must be made within three months of the registration, and at least once in every 12 month period: $\mathrm{s} 51$.

[56] School Education Act 1999 (WA) s 53.

[57] Curriculum Council Act 1997 (WA) s 11.

[58] Home Education. Department of Education and Training. Government of Western Australia. http://www.eddept.wa.edu.au/regframe/index.cfm.

[59] Education Act 1994 (Tas) s 17.

[60] This is similar to New Zealand as outlined above.

[61] See s 81A Education Act 1972 (SA).

[62] Education Act 1996 (NT) s 21(1)(b).

[63] This is also the case in New Zealand where it causes homeschoolers some concern.

[64] Information Booklet for Parents Applying for Home Education, Northern Territory Department of Employment, Education and Training.

[65] Education (General Provisions) Act 2006 (Qld); Education and Training Reform Act 2006 (Vic).

[66] Education and Training Reform Bill - Home Schooling Consultation. http://www.det.vic.gov.au/det/resources/edtrainreform-homeschooling.

[67] Education and Training Reform Bill - Home Schooling Consultation. http:www.det.vic.gov.au/det/resources/edtrainreform-homeschooling.

[68] Education and Training Reform Act 2006 (Vic), Clause 5.8.4.1(b).

[69] See New Zealand Legal and Administrative Issues. http://www.home.school.nz/homelaw.shtml.

[70] Homeschooling: Don’t 'Fix’ What Isn’t Broken. Home School Legal Defense Association. http://www/hslda.org/hs/international/Australia/.

[71] In its March 2001 report, ERO stated that in the reviews conducted in the period from 1999 to 2001 $90 \%$ were satisfactory; the conclusion in $7 \%$ was that the children were not taught at least as regularly and as well as in a registered school; and no conclusion could be reached for $2 \%$ of students: ERO Reviews of Homeschooled Students, March 2001. http://www.ero.govt.nz.

[72] On 28 February 2008 the Court of Appeal of the State of California handed down its decision in the case of In Re Rachael L. et al Persons Coming Under the Juvenile Court Law, Jonathon L and Mary Grace L. v Superior Court of the State of California for the County of Los Angeles,(2008) B192878 (Los Angeles County Super. Ct No JD00773), essentially holding that parents do not have a constitutional right to home school their children. The Court held that the parents did not fit within the exemptions to compulsory education contained in the Code which are that the children attend a full time day school or are instructed by a tutor who holds valid teaching credentials (Ed.Code 48222 \& 48224). 
[76] Upheld for example in Arkansas in the case of Murphy v State of Arkansas 852 F.2d 1039 (8 $8^{\text {th }}$ Cir. 1988).

[73] See also the case emanating from the European Court of Human Rights, Konrad v Germany [2003] Application no. 35504/03.

[74] Applying General Laws c.71, Sec.1. This is not the case in other states, for example, Kentucky, South Dakota and Hawaii where there is no qualification requirement mandated for parents - for a full discussion see Cooper, B S \& Sureau J 'The Politics of Homeschooling: New Developments, New Challenges' (2007) 21 Educational Policy 1, 110 -131.

[75] (1987) 399 Mass. 324.

[77] Brunelle v Lynn Public Schools (1998) SJC-07709 at p 4.

[78] In Australia it is difficult to obtain accurate statistics due to the varying state and territory provisions for dispensation from compulsory education and registration for home schooling, and anecdotally, the failure of many home-schooling parents to take any formal action. A study undertaken in Queensland in 2003 showed an increase from 907 in 1996 to 1474 in 2002 of parents who had applied for dispensation from compulsory enrolment for their children. Homeschooling organizations, from their experience and using Queensland as an example, report an increase in the numbers of children being schooled at home throughout Australia.

[79] In New Zealand, the number of children being schooled at home increased 22.8\% from 1988 to 2007. www.educationcounts.govt.nz/statistics.

[80] See the National Center for Educational Statistics. http://nces.ed.gov/pubs2006/homeschool.estimated.asp. 